\title{
Se recupera la obra pictórica de Pedro de Campaña en la Catedral de Córdoba
}

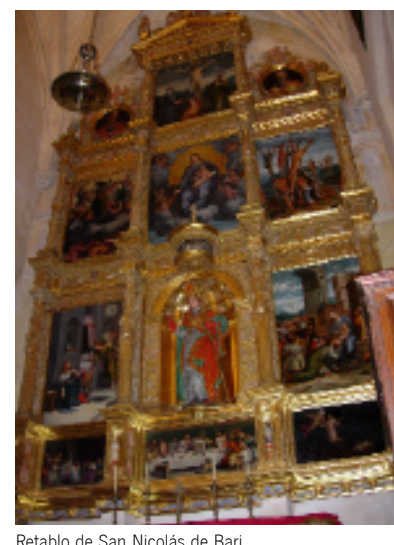

Retablo de San Nicolás de Bar
La última restauración del retablo catedralicio cordobés de San Nicolás de Bari puede ser visitada desde el pasado 23 de diciembre, acompañada de un dispositivo de difusión para su mejor lectura y comprensión previsto por el Cabildo Catedralicio. Gracias a esta intervención, es posible apreciar la recuperación del estado original de las pinturas renacentistas del flamenco Pedro de Campaña que componen este retablo de estilo plateresco.

La pieza ocupa la parte central de la capilla del mismo nombre y fue ejecutada en 1556, en el recinto construido años antes por el arquitecto Hernán Ruiz I, para el canónigo don Bartolomé de León. Posteriormente, el 7 de mayo de 1556, Juan de Leiva, sobrino del segundo fundador de la capilla, acordó con Francisco de Castillejo hacer el dorado, pintado y estofado del retablo, según las condiciones dadas por Hernán Ruiz II. La imagen del titular de la capilla, San Nicolás de Bari, es obra de Francisco Martínez, siendo contratada el 26 de junio de 1549, aunque dorada y estofada en la siguiente centuria.

Destaca de entre las pinturas del retablo, una escena donde se reflejan sus influencias italoflamencas. En la tabla de La Anunciación se aprecia el detallismo tan característico de las obras flamencas, como la descripción de las actividades hogareñas y el pormenorizado mobiliario, mientras que el movimiento de las figuras es típico del modelo manierista.

Sus luces están claramente contrastadas, buscando efectos que refuerzan la expresividad física de los distintos pasajes que se describen junto a los rostros de los personajes. De esta manera consigue escenas llenas de emotividad, dramáticas e intensas, de gran sencillez y monumentalidad, como, por ejemplo, La Batalla de los ángeles.

Se trata en definitiva de excepcionales obras pictóricas, tales como: El Lavatorio, La Santa Cena, La Oración en el Huerto de Getsemaní, La Adoración de los Reyes, La Virgen con Niño, El Martirio de San Bartolomé y los tondos de San Pedro y San Pablo; estando coronado todo el conjunto por El Calvario.

El procedimiento aplicado a las tablas renacentistas ha sido consecuencia de un examen visual, además de realizar una serie de estudios químicos y biológicos, unidos a los radiográficos, que determinaron el estado de conservación.

El tratamiento de diversas patologías que presentaba el retablo ha sido uno de sus objetivos, si- guiendo posteriormente los siguientes pasos en la restauración:

> La consolidación y desinsectación de los elementos estructurales del retablo provocados por ataques de xilófagos.

> La eliminación de varias capas de la superficie pictórica superpuesta a lo largo de los siglos, y que ocultaban el valioso dorado y estofado de la carpintería. La más reciente de ellas, de un tono verde azulado, distorsionaba profundamente la policromía primigenia, en la que la encarnación, el dorado y estofado eran realmente magistrales.

> Finalmente, las tablas al óleo vuelven a lucir su esplendor, gracias a la labor de limpieza, consolidación y reintegración cromática de las mismas.

\section{Pedro de Campaña}

Nacido en Bruselas en 1503 en el seno de la familia Kempeneer, fue un pintor de gran importancia, discípulo de Rafael de Urbino. Formándose en Italia, aprendió el estilo de Miguel Ángel y Rafael Sanzio, sin embargo nunca perdió completamente aquella técnica seca y detallista de trabajar la factura de sus obras, tan típicamente flamenca.

A mediados del siglo XVI está trabajando en la populosa Sevilla, donde dejó algunas de sus mejores muestras de producción artística, entre las que destaca el Descendimiento de la Catedral de Sevilla o las que se encuentran en la Iglesia de Santa Ana. A Córdoba llegará expresamente para ejecutar el encargo del proyecto pictórico del retablo catedralicio, comenzando el 2 de noviembre de 1556, para finalizar el 26 de noviembre de 1557.

El autor, que supo suavizar su formación italiana con el estudio de la escultura clásica observando la naturaleza, muestra en sus pinturas al óleo unas características típicamente manieristas. Prueba de ello es su gran dominio del dibujo, la rica y variada paleta de color o la utilización de una gama de colores muy brillantes.

Rafael Mendoza Yusta

Beatriz Diaz Contreras 